\title{
Sorghum yield after liming and combinations of phosphorus sources
}

\author{
Thiago C. Silveira ${ }^{1}$, Rodinei F. Pegoraro ${ }^{2}$, Marcos K. Kondo ${ }^{1}$, Arley F. Portugal ${ }^{3} \&$ Álvaro V. Resende ${ }^{3}$ \\ ${ }^{1}$ Universidade Estadual de Montes Claros/Departamento de Ciências Agrárias. Janaúba, MG. E-mail: thiagocorrea.cm@hotmail.com.br - ORCID: 0000- \\ 0003-3042-9652; marcos.kondo@unimontes.br - ORCID: 0000-0001-6875-4907 \\ ${ }^{2}$ Universidade Federal de Minas Gerais/Instituto de Ciências Agrárias. Montes Claros, MG. E-mail: rodinei_pegoraro@yahoo.com.br (Corresponding \\ author) - ORCID: 0000-0002-8692-9296 \\ ${ }^{3}$ Embrapa Milho e Sorgo. Sete Lagoas, MG. E-mail: arley.portugal@embrapa.br - ORCID: 0000-0001-6056-3233; alvaro.resende@embrapa.br - ORCID: \\ 0000-0001-5438-4052
}

\section{Key words: \\ residual fertilization \\ phosphorus content \\ agronomic efficiency index}

\begin{abstract}
A B S T R A C T
Phosphate fertilization has increased sorghum yield, but few studies are available on sorghum production and efficient fertilizer management related to liming and phosphorus $(\mathrm{P})$ sources. This work evaluates production, dry matter partitioning and agronomic efficiency (AEI) in successive sorghum cycles after application of limestone and combinations of phosphorus sources. Two cycles were conducted in sequence in the same experimental field, in a $2 \times 6$ factorial scheme, corresponding to soil with or without liming and six combinations of $\mathrm{P}_{2} \mathrm{O}_{5}$ sources: control $\left(0 \mathrm{~kg} \mathrm{ha}^{-1} \mathrm{P}_{2} \mathrm{O}_{5}\right), 100 \%$ Itafós natural phosphate $(\mathrm{NP}), 75 \% \mathrm{NP}$ $+25 \%$ single superphosphate (SS), $50 \% \mathrm{NP}+50 \%$ SS, $25 \% \mathrm{NP}+75 \%$ SS and $100 \%$ SS. Pots with capacity for $8 \mathrm{dm}^{3}$ were used in a randomized block design with four replicates. The first cycle, conducted in the summer/autumn season, reached the highest dry matter production and $\mathrm{P}$ accumulation in treatments with higher SS proportions, leading to higher AEI. Subsequently, in the second cycle, conducted considering only the residual phosphate fertilization of the first cycle, highest dry matter production and AEI were obtained in the treatment with $100 \%$ or higher proportions of natural phosphate in the presence of liming, most likely due to the gradual release of $\mathrm{P}$.
\end{abstract}

Palavras-chave:

adubação residual conteúdo de fósforo índice de eficiência agronômica

\section{Produção de sorgo cultivado após aplicação de calcário e combinação de diferentes fontes de fósforo}

\begin{abstract}
R E S U M O
A adubação fosfatada tem propiciado aumentos na produção de sorgo, mas são escassos estudos relacionados ao uso de fontes de fósforo e calcário na sua produção e uso eficiente da adubação. Neste sentido, objetivou-se avaliar a produção e partição de matéria seca, e a eficiência agronômica em cultivos sucessivos de sorgo após combinações com fontes de fósforo e calcário. Para tanto, foram conduzidos dois cultivos em sequência, no esquema fatorial $2 \times 6$, com duas doses de calcário (com e sem calcário) e seis combinações com fonte de $\mathrm{P}_{2} \mathrm{O}_{5}$ : testemunha $\left(0 \mathrm{~kg} \mathrm{ha}^{-1}\right.$ de $\left.\mathrm{P}_{2} \mathrm{O}_{5}\right), 100 \%$ de fosfato natural Itafós (NP), $75 \%$ $\mathrm{NP}+25 \%$ de superfosfato simples (SS), $50 \% \mathrm{NP}+50 \% \mathrm{SS}, 25 \% \mathrm{NP}+75 \%$ SS e $100 \%$ SS. Utilizou-se o delineamento em blocos casualizados com quatro repetições e os cultivos foram conduzidos em vasos de $8 \mathrm{dm}^{3}$. No primeiro cultivo, conduzido no período de verão/ outono obteve-se maiores produções de matéria seca e acúmulo de $\mathrm{P}$ nos tratamentos com maiores proporções de SS, implicando na obtenção de maior índice de eficiência agronômica (IEA). No segundo cultivo, realizado logo após, e considerando somente a adubação fosfatada residual do primeiro, maiores produções de matéria seca e IEA foram observados no tratamento com o uso integral ou maiores proporções de fosfato natural, na presença de calcário, possivelmente em decorrência da liberação gradual de fósforo.
\end{abstract}




\section{INTRODUCTION}

Phosphorus (P) is one of the most limiting macronutrients for biomass and grain production in tropical soils (Restelatto et al., 2017). Thus, phosphate fertilization management along with liming and the combination of soluble and natural phosphates favor absorption efficiency and increase production in agricultural crops (Oliveira et al., 2007; Too et al., 2014; Costa et al., 2016).

Sorghum is an agricultural crop with national and global importance due to its climatic rusticity and versatility of use in the production of grains and forage for animal feed, and in bioenergy production (Cruz et al., 2009; Parente et al., 2014; Pereira et al., 2015). Although rustic, sorghum is considered as demanding in $\mathrm{P}$, and scientific studies have demonstrated positive effect of $\mathrm{P}$ fertilization on its dry matter and grain production (Costa et al., 2008; Cruz et al., 2009).

Phosphate fertilization in the sorghum crop is basically performed with soluble sources at sowing, but the combined use with natural phosphates, due to the gradual release of $\mathrm{P}$ over time, may balance the supply of $\mathrm{P}$ during the cycles. In this context, scientific studies have demonstrated the agronomic and economic importance of using natural phosphates because they contribute to better $\mathrm{P}$ use by plants along the cultivation time (Ono et al., 2009; Souza et al., 2014).

Limestone application in acid soils favors root development and $\mathrm{P}$ absorption by plants, due to the neutralization of $\mathrm{Al}$, increase in soil $\mathrm{pH}$ and increase in the availability of $\mathrm{Ca}$ and $\mathrm{Mg}$. However, liming prior to fertilization with natural phosphate increases soil $\mathrm{pH}$, which may reduce the gradual solubility of the $\mathrm{P}$ present in the natural source (Dias et al., 2015). Therefore, this study aimed to evaluate dry matter production and agronomic efficiency in successive cycles of sorghum after fertilization with combinations of natural phosphate and soluble phosphate, in soils subjected or not to liming.

\section{Material ANd Methods}

The study was carried out in the municipality of Janaúba-

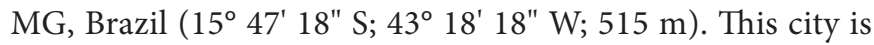
located in the Brazilian semi-arid region under Aw climate, according to Köppen's classification. The mean annual rainfall of the region is approximately $870 \mathrm{~mm}$, mean annual temperature is $24^{\circ} \mathrm{C}$, insolation is $2,700 \mathrm{~h}$ per year and mean relative humidity is $65 \%$.

The study comprised two pot experiments, which were installed in sequence in a Red Yellow Latosol previously cultivated with castor bean for two years, in an area divided according to presence and absence of liming. In the beginning of castor bean cultivation, $3,600 \mathrm{~kg} \mathrm{ha}^{-1}$ of magnesium limestone were applied, recommended based on soil analysis and according to the method of neutralizing $\mathrm{Al}^{3+}$ and increasing $\mathrm{Ca}$ and Mg contents (Alvarez V. \& Ribeiro, 1999). Prior to castor bean cultivation, this area had been managed with Brachiaria grass for many years.

Two composite soil samples of treatments with and without liming were collected in the 0-0.20 m layer, air dried, pounded to break up clods, sieved through a $2-\mathrm{mm}$ mesh and homogenized for chemical and physical characterization (EMBRAPA, 1997). Twenty single samples were collected to form one composite sample, and the results for the soil with and without liming were respectively: $\mathrm{pH}\left(\mathrm{H}_{2} \mathrm{O}\right)=5.40$ and 6.5; $\mathrm{OM}=2.76$ and $2.70 \% ; \mathrm{P}=3.80$ and $4.4 \mathrm{mg} \mathrm{dm}^{-3}$ and $\mathrm{K}=109.00$ and $113.00 \mathrm{mg} \mathrm{dm}^{-3}$ (Mehlich-1); $\mathrm{Al}^{3+}=0.20$ and $0 \mathrm{cmol}_{c} \mathrm{dm}^{-3}, \mathrm{Ca}^{2+}=2.50$ and $3.60 \mathrm{cmol}_{c} \mathrm{dm}^{-3}$ and $\mathrm{Mg}^{2+}=0.60$ and $1.00 \mathrm{cmol}_{\mathrm{c}} \mathrm{dm}^{-3}\left(1 \mathrm{~mol} \mathrm{~L}^{-1} \mathrm{KCl}\right) ; \mathrm{H}^{+}+\mathrm{Al}^{3+}=2.90$ and $1.60 \mathrm{cmol} \mathrm{dm}^{-3}\left(0.5 \mathrm{~mol} \mathrm{~L}^{-1}\right.$ calcium acetate, $\left.\mathrm{pH} 7.0\right) ; \mathrm{SB}=3.40$ and $4.90 \mathrm{cmol} \mathrm{dm}_{\mathrm{c}}^{-3} ; \mathrm{t}=3.60$ and $4.90 \mathrm{cmol} \mathrm{dm}_{\mathrm{c}} \mathrm{dm}^{-3} \mathrm{~T}=6.30$ and $6.5 \mathrm{cmol}_{\mathrm{c}} \mathrm{dm}^{-3} ; \mathrm{V}=54$ and $75 \%$; and $\mathrm{m}=3$ and $0 \%$.

The study was set in a randomized block design, with four replicates in a $2 \times 6$ factorial scheme, corresponding to two liming managements (with and without limestone application) and six forms of phosphate fertilization: Control (without phosphate fertilization) and combinations of $\mathrm{P}_{2} \mathrm{O}_{5}$ sources at dose of $90 \mathrm{~kg} \mathrm{ha}^{-1}: 100 \%$ natural phosphate (NP) (280 $\left.\mathrm{mg} \mathrm{dm}^{-3} \mathrm{NP}\right)$; $75 \% \mathrm{NP}+25 \%$ single superphosphate (SS) $\left(210 \mathrm{mg} \mathrm{dm}^{-3} \mathrm{NP}\right.$ $\left.+62.5 \mathrm{mg} \mathrm{dm}^{-3} \mathrm{SS}\right) ; 50 \% \mathrm{NP}+50 \% \mathrm{SS}\left(140 \mathrm{mg} \mathrm{dm}^{-3} \mathrm{NP}+\right.$ $\left.125 \mathrm{mg} \mathrm{dm}^{-3} \mathrm{SS}\right) ; 25 \% \mathrm{NP}+75 \% \mathrm{SS}\left(70 \mathrm{mg} \mathrm{dm}^{-3} \mathrm{NP}+187.5\right.$ $\mathrm{mg} \mathrm{dm}{ }^{-3} \mathrm{SS} ; 100 \% \mathrm{SS}$ ( $250 \mathrm{mg} \mathrm{dm}^{-3} \mathrm{SS}$ ). The experiment used the natural phosphate Itafós of sedimentary origin, also known as Arraias phosphate, obtained from phosphorites of the Sete Lagoas Formation, basal portion of the Bambuí group, region of Campos Belos, GO, and Arraias-TO (Monteiro, 2009). This natural phosphate showed the following chemical characteristics (Brasil, 2014): $\mathrm{SiO}_{2}=44.01 \mathrm{dag} \mathrm{kg}{ }^{-1} ; \mathrm{Al}_{2} \mathrm{O}_{3}=5.97 \mathrm{dag} \mathrm{kg}^{-1}$; $\mathrm{Fe}_{2} \mathrm{O}_{3}=2.47 \mathrm{dag} \mathrm{kg}^{-1} ; \mathrm{MgO}=0.79 \mathrm{dag} \mathrm{kg}^{-1} ; \mathrm{CaO}=23.85 \mathrm{dag} \mathrm{kg}^{-1} ;$ $\mathrm{Na}_{2} \mathrm{O}=0.02$ dag kg${ }^{-1} ; \mathrm{K}_{2} \mathrm{O}=1.05 \mathrm{dag} \mathrm{kg}^{-1} ; \mathrm{P}_{2} \mathrm{O}_{5}=16.21 \mathrm{dag} \mathrm{kg}^{-1}$; $\mathrm{MnO}=0.15$ dag kg${ }^{-1} ; \mathrm{TiO}_{2}=0.24 \mathrm{dag} \mathrm{kg}^{-1} ; \mathrm{Ni}=74.00 \mathrm{mg} \mathrm{kg}^{-1}$; $\mathrm{Ba}=626.00 \mathrm{mg} \mathrm{kg}^{-1} ; \mathrm{Co}=15.00 \mathrm{mg} \mathrm{kg}^{-1} ; \mathrm{Mo}=1.80 \mathrm{mg} \mathrm{kg}^{-1}$; $\mathrm{Cu}=36.10 \mathrm{mg} \mathrm{kg}^{-1} ; \mathrm{Pb}=14.60 \mathrm{mg} \mathrm{kg}^{-1} ; \mathrm{Zn}=244.00 \mathrm{mg} \mathrm{kg}^{-1}$.

The first experiment was conducted in pots containing $8 \mathrm{dm}^{3}$ of soil. Sowing was performed in the summer/autumn period, and the experiment was carried out in open field with two plants of BRS 511 saccharine sorghum per pot. Manual irrigation maintained the soil at $70 \%$ field capacity and no significant natural rainfalls occurred along the cultivation period. Top-dressing fertilization was the same for all treatments, with $100 \mathrm{mg} \mathrm{dm}^{-3}$ of $\mathrm{N}$, in the form of urea, and $150 \mathrm{mg} \mathrm{dm}^{-3}$ of $\mathrm{K}_{2} \mathrm{O}$, in the form of potassium chloride, directly applied on soil surface and split into two applications, the first one at 20 days after sowing (DAS) and the second one at 40 DAS. Along the study, plant height was measured every two weeks, from 15 to $90 \mathrm{DAS}$, totaling six measurements, from base to apex.

Plants were harvested at 100 DAS when the grains reached the hard-farinaceous stage. Plants were separated into four components: leaves, stem, roots and panicle, for dry matter characterization in the different organs. Panicles were dried in an oven at $105^{\circ} \mathrm{C}$, for $24 \mathrm{~h}$, and grains were manually separated and weighed, to determine moisture content and grain dry matter production per plant, with correction to $13 \%$ moisture content. The other plant parts were dried in forced-air oven at $65{ }^{\circ} \mathrm{C}$, for $72 \mathrm{~h}$. After drying, the samples were weighed to determine the total dry matter production per pot. In addition, $\mathrm{P}$ contents present in the vegetative components (leaves, 
stems and roots) of the sorghum crop were also characterized according to Silva (2009), and the P absorbed by the crop was estimated by multiplying the obtained and the dry matter of the vegetative component.

To isolate the effect of the application of natural phosphates on crop dry matter production, the Agronomic Efficiency Index (AEI) of the natural phosphate (NP) was calculated based on the dry matter content obtained in the control (zero dose), using the following equation (Eq. 1): where:

$$
\mathrm{AEI}=\frac{(\mathrm{DM} \mathrm{NP})-(\mathrm{DM} \text { control })}{(\mathrm{DM} \mathrm{SS})-(\mathrm{DM} \text { control })} \cdot 100
$$

AEI - agronomic efficiency index, \%;

DM NP - dry matter in the treatment with natural phosphate, g plant ${ }^{-1}$;

DM control - dry matter in the control, g plant ${ }^{-1}$; and,

DM SS - dry matter in the treatment with single superphosphate, g plant $^{-1}$.

The second experiment was conducted in the soil and pots of the first cycle, following the same treatments, but suspending phosphate fertilization to evaluate the residual effect of the combinations between $\mathrm{P}$ sources on the production and AEI of BRS 511 saccharine sorghum. After the first experiment, the Red Yellow Latosol was pounded to break up clods, sieved through a $2 \mathrm{~mm}$ mesh and transferred back to the pots, in a volume of $6 \mathrm{dm}^{3}$ per pot, due to the removal of $2 \mathrm{dm}^{3}$ during root extraction.

The conditions, methods and characteristics evaluated in the second study corresponded to those described for the first one. The data were subjected to analysis of variance and means were compared by Tukey test ( $\mathrm{p} \leq 0.05)$, using the statistical program Sisvar (Ferreira, 2014).

\section{Results AND Discussion}

The production characteristics root dry matter and grain dry matter were influenced ( $\mathrm{p} \leq 0.05$ ) by the interaction between limestone and $\mathrm{P}$ sources combinations. The other characteristics, total dry matter, leaf dry matter and stem dry matter, were influenced by the isolated factors, use of limestone or $\mathrm{P}$ combinations.

Total dry matter, leaf dry matter and stem dry matter were higher in the soil without liming, in comparison to that with limestone, in the first cycle, and total dry matter and stem dry matter were also higher in soil without liming in the second cycle, evaluating the residual effect of $\mathrm{P}$ (Table 1). This indicates adequate capacity of development by the sorghum crop in soils with intermediate acidity $\left(\mathrm{pH}_{(\mathrm{H} 2 \mathrm{O})}=5.4\right)$ and high and intermediate contents of $\mathrm{Ca}$ and $\mathrm{Mg}$, respectively, according to the chemical characterization of the soil used in the study. The soil without liming also showed high natural fertility and adequate condition of base saturation percentage $(\mathrm{V}=54 \%)$ for sorghum cultivation, whereas in the soil with liming base saturation was equal to $75 \%$, higher than $50 \%$, indicated for sorghum cultivation, as described by Alvarez V. \& Ribeiro
Table 1. Means of total dry matter (TDM), leaf dry matter (LDM) and stem dry matter (SDM) after fertilization with combinations of phosphate fertilizers (natural phosphate and single superphosphate) in the absence and presence of limestone, for the first and second cycles of saccharine sorghum

\begin{tabular}{lccc}
\hline \multirow{4}{*}{ Limestone } & TDM & LDM & SDM \\
\cline { 2 - 4 } & \multicolumn{3}{c}{ g plant $^{-1}$} \\
With limestone & $43.34 \mathrm{~b}$ & $5.82 \mathrm{~b}$ & $24.46 \mathrm{~b}$ \\
Without limestone & $53.82 \mathrm{a}$ & $6.89 \mathrm{a}$ & $33.92 \mathrm{a}$ \\
Mean & 48.61 & 6.35 & 28.18 \\
CV (\%) & 29.10 & 15.56 & 31.60 \\
\hline \multicolumn{4}{c}{ Second cycle (residual effect of P) } \\
With limestone & $16.36 \mathrm{~b}$ & $2.01 \mathrm{a}$ \\
Without limestone & $17.66 \mathrm{a}$ & $1.21 \mathrm{~b}$ & $10.11 \mathrm{~b}$ \\
Mean & 17.01 & 2.11 & $11.02 \mathrm{a}$ \\
CV (\%) & 11.16 & 8.30 & 10.57 \\
\hline
\end{tabular}

Means followed by the same lowercase letters in columns do not differ by Tukey test $(p \geq 0.05)$

(1999). High V\% in the soil with liming may have contributed to lower dry matter production in the sorghum vegetative components. Predebon et al. (2010) described the inexistence of effect of liming on the dry matter production of Tifton grass. However, under acid soil conditions, other studies have reported positive effect of liming on the increase of dry matter production in the sorghum crop (Too et al., 2014; Costa et al., 2016), due to the greater Ca supply and neutralization of $\mathrm{Al}^{+3}$ (Costa et al., 2016), condition of acidity that did not occur in the present study, with saccharine sorghum.

In the first cycle of sorghum, treatments with higher proportion of single superphosphate fertilizer (100, 75, 50 and $25 \%$ ) led to higher production of total dry matter and leaf dry matter (Table 2). Stem dry matter in the first cycle was not significantly influenced $(p>0.05)$ by the combinations of $P$ sources. Nevertheless, for the residual effect of phosphate fertilization (second cycle), higher production of total dry matter and stem dry matter was obtained in treatments with higher proportions of natural phosphate. These results were attributed to the higher solubility and availability of $\mathrm{P}$ in the treatment fertilized with single superphosphate in the first cycle and to the positive residual effect of the natural phosphate in the second cycle.

Table 2. Total dry matter (TDM), leaf dry matter (LDM), stem dry matter (SDM) after fertilization with combinations of phosphate fertilizers (NP - natural phosphate; SS - single superphosphate) in the absence and presence of limestone, for the first and second cycles of saccharine sorghum

\begin{tabular}{lccccc}
\hline \multirow{2}{*}{ Treatments } & TDM & LDM & TDM & LDM & SDM \\
\cline { 2 - 6 } & First cycle & \multicolumn{4}{c}{$\begin{array}{c}\text { Second cycle } \\
\text { (residual effect of P) }\end{array}$} \\
\cline { 2 - 6 } Control & $35.88 \mathrm{c}$ & $5.81 \mathrm{~b}$ & $13.25 \mathrm{c}$ & $1.77 \mathrm{~b}$ & $8.71 \mathrm{~b}$ \\
$100 \% \mathrm{NP}$ & $37.94 \mathrm{bc}$ & $5.99 \mathrm{ab}$ & $20.05 \mathrm{a}$ & $2.31 \mathrm{a}$ & $11.98 \mathrm{a}$ \\
$75 \% \mathrm{NP}+25 \% \mathrm{SS}$ & $47.13 \mathrm{abc}$ & $5.51 \mathrm{~b}$ & $18.52 \mathrm{ab}$ & $2.24 \mathrm{a}$ & $11.34 \mathrm{a}$ \\
$50 \% \mathrm{NP}+50 \% \mathrm{SS}$ & $49.64 \mathrm{abc}$ & $7.32 \mathrm{a}$ & $16.90 \mathrm{~b}$ & $2.12 \mathrm{a}$ & $10.61 \mathrm{ab}$ \\
$25 \% \mathrm{NP}+75 \% \mathrm{SS}$ & $59.00 \mathrm{ab}$ & $6.67 \mathrm{ab}$ & $16.70 \mathrm{~b}$ & $2.16 \mathrm{a}$ & $10.55 \mathrm{ab}$ \\
$100 \% \mathrm{SS}$ & $62.09 \mathrm{a}$ & $6.85 \mathrm{ab}$ & $16.65 \mathrm{~b}$ & $2.06 \mathrm{a}$ & $10.22 \mathrm{ab}$ \\
Mean & 48.61 & 6.36 & 17.01 & 2.11 & 13.83 \\
CV (\%) & 29.10 & 15.56 & 11.16 & 8.30 & 10.57 \\
\hline
\end{tabular}

Means followed by the same lowercase letters in the columns do not differ by Tukey test $(p \geq 0.05)$ 
This residual effect is characterized by the lower solubilization speed and gradual supply of $\mathrm{P}$, being indicated for cultivation of perennial plants or successive crops (González et al., 2014; Souza et al., 2014; Dias et al., 2015). Natural phosphates are equivalent to soluble phosphates regarding the accumulated production over various cycles. Caione et al. (2011) report that, over time, less soluble sources contribute to the increase in production, because they have greater residual effect.

Results obtained in our study were also related to the demand of $\mathrm{P}$ for sorghum development. Adequate $\mathrm{P}$ supply in the initial growth stages is fundamental to increase crop yield. Phosphorus is essential in plant metabolic processes, such as the increase in $\mathrm{N}$ absorption efficiency, new tissue formation, increment in leaf area index and longevity of photosynthetically active leaves, increasing the effectiveness of solar radiation use and dry matter accumulation (Taiz \& Zeiger, 2013).

Highest production of root dry matter, grain dry matter and root/shoot ratio in the first cycle were obtained in treatments with higher proportions of single superphosphate, especially in soils with limestone (Table 3). These results agree with those obtained by Cruz et al. (2009), who observed increments in dry matter production and grain yield of sorghum in response to doses of phosphate fertilization, in soils under limestone application.

Nonetheless, in the absence of limestone the use of 100\% NP led to similar GDM means compared with the treatment fertilized with $100 \%$ SS. Possibly, the absence of limestone contributed to maintaining an acid environment in the soil solution, a phenomenon necessary for greater solubilization of the natural phosphate, contributing to the increase in sorghum grain production after fertilization with natural phosphate.

In the treatment with $100 \%$ SS as P source, limestone increased sorghum RDM compared with the soil without liming (Table 3). Under this condition, the increase in soil
$\mathrm{pH}$ due to liming may have reduced phosphate adsorption by the clay minerals, increasing its availability in the soil and absorption by roots, which can contribute to increasing root production.

In the second cycle, for the interaction between limestone and $\mathrm{P}$ sources, highest means of grain dry matter were obtained with the addition of higher proportions of natural phosphate $(75 \% \mathrm{NP}+25 \% \mathrm{SS})$ or $100 \%$ natural phosphate, in the soils that received or not liming (Table 3), evidencing the greater capacity of natural phosphate to gradually release $\mathrm{P}$ to plants along the cycles, in comparison to single superphosphate. Oliveira et al. (2007) observed in the second year of cultivation greater residual effect of magnesium thermophosphate on the dry matter production of Brachiaria brizantha in comparison to the use of triple superphosphate and single superphosphate.

The $\mathrm{P}$ contents in the plant components (leaves, stems and roots) were influenced by the interactions between $\mathrm{P}$ sources combination and limestone, for both cycles of saccharine sorghum (Table 4).

In the first cycle, highest $\mathrm{P}$ accumulations in the plant components were obtained under application of $100 \%$ SS (with limestone) or $25 \% \mathrm{NP}+75 \% \mathrm{SS}$ (without limestone), not differing statistically from most treatments with combinations of P. In the second cycle, highest P contents in sorghum vegetative components were obtained in treatments with higher proportion or $100 \%$ NP. These results indicate that the use of reactive sources of $\mathrm{P}$ in combination with natural sources of sedimentary origin contributes to the initial phosphate nutrition and can be considered in the residual management of the fertilization for the second cycle. These results corroborate those obtained for dry matter production in the components of saccharine sorghum, i.e., in treatments with higher P content there was an increase in the dry matter production in most plant components.

Table 3. Root dry matter (RDM), grain dry matter (GDM) and root/shoot ratio (R/S) after fertilization with combinations of phosphate fertilizers (NP - natural phosphate; SS - single superphosphate) in the absence (AL) and presence (PL) of limestone, in the first and second cycle of saccharine sorghum

\begin{tabular}{|c|c|c|c|c|c|c|}
\hline \multirow{3}{*}{ Treatments } & \multicolumn{2}{|c|}{ RDM } & \multicolumn{2}{|c|}{ GDM } & \multicolumn{2}{|c|}{$R / S$} \\
\hline & $\mathbf{A L}$ & PL & $\overline{A L}$ & PL & $\overline{A L}$ & PL \\
\hline & \multicolumn{6}{|c|}{ g plant $^{-1}$} \\
\hline & \multicolumn{6}{|c|}{ First cycle } \\
\hline Control & $4.92 \mathrm{~d} \mathrm{~A}$ & $5.26 \mathrm{~cd} \mathrm{~A}$ & $3.18 \mathrm{c} \mathrm{A}$ & 0.80 c B & 0.06 b B & $0.13 \mathrm{~b} \mathrm{~A}$ \\
\hline $100 \% N P$ & $6.62 \mathrm{~cd} \mathrm{~A}$ & $3.01 \mathrm{~d} \mathrm{~B}$ & $5.46 \mathrm{ab} \mathrm{A}$ & 1.48 c B & $0.08 \mathrm{~b} \mathrm{~A}$ & $0.07 \mathrm{~b} \mathrm{~A}$ \\
\hline $75 \% N P+25 \% S S$ & $4.99 \mathrm{~d} \mathrm{~A}$ & $5.80 \mathrm{~cd} \mathrm{~A}$ & $2.82 \mathrm{c} \mathrm{B}$ & $5.83 \mathrm{ab} A$ & $0.07 \mathrm{~b} \mathrm{~A}$ & $0.07 \mathrm{~b} \mathrm{~A}$ \\
\hline $50 \% N P+50 \% S S$ & 8.79 bc A & 7.57 bc A & 3.74 bc $A$ & $4.82 \mathrm{ab} A$ & $0.09 a b A$ & $0.10 \mathrm{~b} \mathrm{~A}$ \\
\hline $25 \% N P+75 \% S S$ & 16.19 a A & 9.50 b B & 3.88 bc B & 6.44 a A & 0.17 a $\mathrm{A}$ & $0.12 \mathrm{~b} \mathrm{~A}$ \\
\hline $100 \% S S$ & 9.58 b B & 22.50 a A & 6.05 a $A$ & $4.23 \mathrm{~b} \mathrm{~B}$ & $0.09 a b B$ & 0.30 a $\mathrm{A}$ \\
\hline Mean & 8.51 & 8.94 & 4.19 & 3.94 & 0.09 & 0.13 \\
\hline \multirow[t]{2}{*}{ CV (\%) } & 15.64 & 15.64 & 24.73 & 24.73 & 34.00 & 34.00 \\
\hline & \multicolumn{6}{|c|}{ Second cycle (residual effect of $\mathrm{P}$ ) } \\
\hline Control & 2.06 b A & $1.28 \mathrm{c} \mathrm{A}$ & 0.94 c B & 1.23 c A & 0.17 a A & 0.11 c B \\
\hline $100 \% \mathrm{NP}$ & 3.38 a $A$ & 3.72 a $A$ & $2.32 \mathrm{a} \mathrm{A}$ & 2.07 a B & 0.19 a B & 0.24 a $A$ \\
\hline $75 \% N P+25 \% S S$ & $2.70 a b \mathrm{~A}$ & $3.15 \mathrm{ab} A$ & $2.14 \mathrm{a} \mathrm{A}$ & 1.86 a B & 0.16 a A & $0.21 a b A$ \\
\hline $50 \% N P+50 \% S S$ & 2.30 ab A & $2.80 \mathrm{ab} A$ & $1.60 \mathrm{~b} \mathrm{~A}$ & 1.62 b A & 0.16 a A & $0.19 a b A$ \\
\hline $25 \% N P+75 \% S S$ & 2.62 ab A & $2.15 \mathrm{bc} \mathrm{A}$ & $1.54 \mathrm{~b} \mathrm{~A}$ & 1.62 b A & 0.17 a A & 0.15 bc $A$ \\
\hline $100 \%$ SS & 3.32 a $A$ & 2.23 bc B & $1.57 \mathrm{~b} \mathrm{~A}$ & 1.59 b A & 0.22 a A & 0.16 bc B \\
\hline Mean & 2.73 & 2.55 & 1.68 & 1.66 & 0.18 & 0.17 \\
\hline CV $(\%)$ & 20.64 & 20.64 & 6.21 & 6.21 & 18.00 & 18.00 \\
\hline
\end{tabular}

Means followed by the same uppercase letters in rows, for limestone, and same lowercase letters in columns, for phosphorus combinations, do not differ by Tukey test ( $p \geq 0.05$ ) 
Table 4. Phosphorus content absorbed by leaves, stems and roots of sorghum in the first and second cycles, after fertilization with combinations of phosphate fertilizers (NP - natural phosphate; SS - single superphosphate) in the absence $(\mathrm{AL})$ and presence $(\mathrm{PL})$ of limestone

\begin{tabular}{|c|c|c|c|c|c|c|}
\hline \multirow{3}{*}{ Treatments } & \multicolumn{2}{|c|}{ Leaves } & \multicolumn{2}{|c|}{ Stems } & \multicolumn{2}{|c|}{ Roots } \\
\hline & AL & PL & AL & PL & AL & PL \\
\hline & \multicolumn{6}{|c|}{ mg plant $^{-1}$} \\
\hline & \multicolumn{6}{|c|}{ First cycle } \\
\hline Control & $7.21 \mathrm{ab} A$ & $4.73 \mathrm{~b} \mathrm{~B}$ & $6.61 \mathrm{c} \mathrm{A}$ & 7.16 b A & 1.47 c A & $1.87 \mathrm{c} \mathrm{A}$ \\
\hline $100 \% \mathrm{NP}$ & 5.57 b A & 5.42 b A & $8.51 \mathrm{bc} A$ & $6.51 \mathrm{~b} \mathrm{~A}$ & $2.45 \mathrm{bc} A$ & $1.75 \mathrm{c} \mathrm{A}$ \\
\hline $75 \% N P+25 \%$ SS & $6.81 a b \mathrm{~A}$ & $5.49 \mathrm{~b} \mathrm{~A}$ & 6.52 c A & 5.80 b A & $1.81 \mathrm{bc} \mathrm{B}$ & $3.13 \mathrm{c} \mathrm{A}$ \\
\hline $50 \% N P+50 \%$ SS & $7.22 \mathrm{ab} A$ & $6.85 \mathrm{ab} A$ & $11.74 \mathrm{ab} A$ & 6.91 b B & $2.61 \mathrm{bc} \mathrm{A}$ & $3.51 \mathrm{c} \mathrm{A}$ \\
\hline $25 \% N P+75 \%$ SS & 8.90 a $A$ & $7.04 \mathrm{ab} A$ & 18.64 a A & 7.63 b B & 6.41 a $A$ & 5.43 b A \\
\hline $100 \% S S$ & $7.01 \mathrm{ab} B$ & 9.32 a $A$ & $14.59 \mathrm{ab} B$ & 17.99 a $A$ & $3.37 \mathrm{~b} \mathrm{~B}$ & 8.61 a $A$ \\
\hline Mean & 7.12 & 6.48 & 11.10 & 8.67 & 3.02 & 4.05 \\
\hline \multirow[t]{2}{*}{ CV (\%) } & 21.75 & 21.75 & 21.97 & 21.97 & 24.66 & 24.66 \\
\hline & \multicolumn{6}{|c|}{ Second cycle (residual effect of $\mathrm{P}$ ) } \\
\hline Control & 1.19 c A & $1.18 \mathrm{C} \mathrm{A}$ & $1.97 \mathrm{~b} B$ & $3.26 \mathrm{~d} A$ & 0.52 a $A$ & $0.45 \mathrm{CA}$ \\
\hline $100 \% \mathrm{NP}$ & 1.92 a B & 2.32 a $A$ & $4.45 \mathrm{aB}$ & 5.39 ab A & 0.98 a B & $1.52 \mathrm{a} A$ \\
\hline $75 \% N P+25 \%$ SS & 1.79 a $\mathrm{A}$ & $1.97 \mathrm{ab} A$ & $2.75 \mathrm{~b} \mathrm{~B}$ & $4.71 \mathrm{bc} A$ & 0.85 a B & $1.21 \mathrm{ab} A$ \\
\hline $50 \% N P+50 \%$ SS & $1.67 \mathrm{ab} A$ & 1.65 b A & $2.61 \mathrm{~b} \mathrm{~B}$ & $4.13 \mathrm{bcd} A$ & 0.67 a $A$ & 0.89 bc $A$ \\
\hline $25 \% N P+75 \%$ SS & $1.23 \mathrm{bc} B$ & $1.89 a b \mathrm{~A}$ & $2.33 \mathrm{~b} \mathrm{~B}$ & 6.46 a $\mathrm{A}$ & 0.71 a A & $0.80 \mathrm{bc} \mathrm{A}$ \\
\hline $100 \% S S$ & 0.99 с B & 1.70 b A & $1.80 \mathrm{~b} \mathrm{~B}$ & $3.36 \mathrm{~cd} A$ & $1.01 \mathrm{a} A$ & $0.70 \mathrm{C} \mathrm{A}$ \\
\hline Mean & 1.46 & 1.78 & 2.65 & 4.55 & 0.79 & 0.92 \\
\hline CV (\%) & 13.07 & 13.07 & 17.87 & 17.87 & 26.97 & 26.97 \\
\hline
\end{tabular}

Means followed by the same uppercase letters in rows, for limestone, and same lowercase letters in columns, for phosphorus combinations, do not differ by Tukey test ( $p \geq 0.05$ )

The highest agronomic efficiency (AEI) in the first cycle corresponded to $157 \%$ and was obtained after phosphate fertilization with $25 \% \mathrm{NP}+75 \% \mathrm{SS}$, in the absence of limestone (Figure 1). In the presence of limestone, the treatment with $100 \%$ SS led to highest AEI, indicating that the use of higher proportion of soluble phosphate after liming or the mixture with lower proportion of natural phosphate in acid soil promotes better $\mathrm{P}$ use by sorghum in the first cycle.

Lower efficiency of natural phosphate, especially in the soil managed with limestone in the first cycle, was attributed to the lower supply of protons in the soil solution along with high concentration of $\mathrm{Ca}^{2+}$. These characteristics of the soil cause imbalance in the dissolution reaction of natural phosphates, reducing the intensity in the release of $\mathrm{P}$ from this fertilizer to the soil (Ono et al., 2009; Fontoura et al., 2010).

In the second cycle, conducted to evaluate the residual effect of $\mathrm{P}$ sources combinations, AEI increased in the treatments with higher proportion of natural phosphate (Figure 1). Application of $100 \% \mathrm{NP}$, in soils with and without liming, led to agronomic efficiency of 219 and $177 \%$, respectively, confirming the greater contribution of these phosphates to P supply along the cultivation time or for subsequent crops, indicating maintenance of soluble forms and low precipitation of $\mathrm{P}$ forms, as reported by Souza et al. (2014). These authors also obtained variation in AEI with the increase in the time of application of Itafós phosphate in the soil and observed values of 44 and $48 \%$ in the first and second years of cultivation, respectively.

Fertilization with natural $\mathrm{P}$ sources has increased the relative efficiency of rock phosphates over time, due to the gradual release and greater protection of $P$ against reactions of fixation or specific adsorption by oxides in the soil, compared with sources of soluble phosphates (Costa et al., 2008; Ono et al., 2009), evidencing the importance of its gradual solubilization for mineral nutrition (Resende et al., 2006).

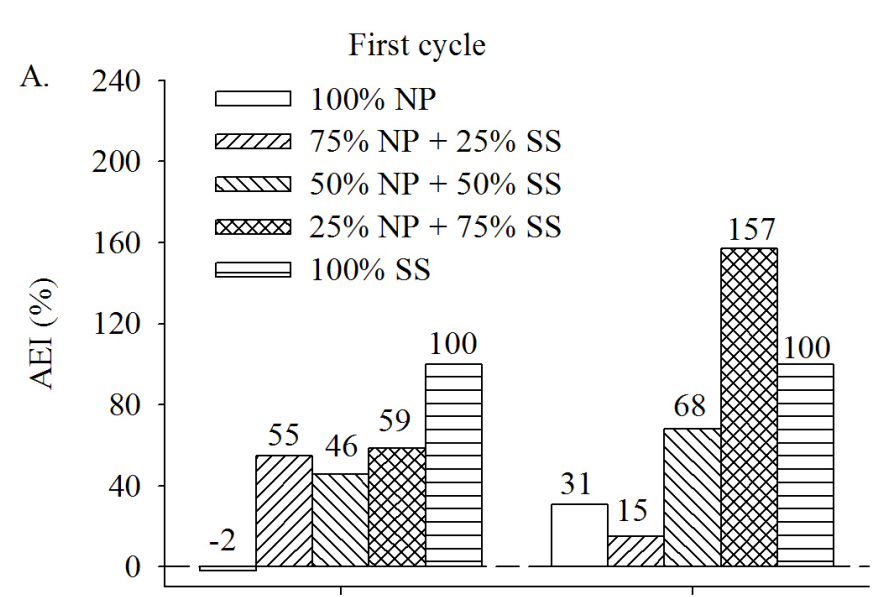

Second cycle (residual effect of P)

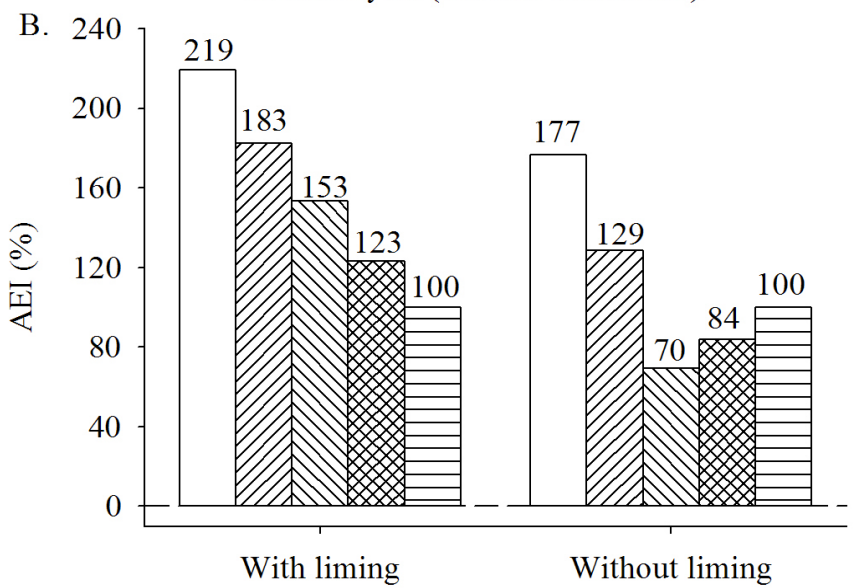

NP - Natural phosphate; SS - Single superphosphate

Figure 1. Agronomic efficiency index (AEI) after fertilization with combinations of phosphate fertilizers in the absence and presence of liming for the first (A) and second (B) cycles

\section{Conclusions}

1. In the first cycle, the absence of limestone and greater proportion of single superphosphate increased sorghum dry 
matter production in comparison to limestone application and use of natural phosphate, and highest agronomic efficiency indices occur in treatments with higher proportion of single superphosphate.

2. In the second cycle, residual effect of fertilization with greater proportion of natural phosphate increases sorghum dry matter production and agronomic efficiency index, in the absence and presence of limestone.

\section{Literature Cited}

Alvarez V., V. H.; Ribeiro, A. C. Calagem. In: Ribeiro, A. C.; Guimarães, P. T. G.; Alvarez V., V. H. Recomendação para o uso de corretivos e fertilizantes em Minas Gerais. Viçosa: Comissão de Fertilidade do Solo do Estado de Minas Gerais, 1999. p.43-60.

Brasil. Ministério da Agricultura, Pecuária e Abastecimento. Manual de métodos analíticos oficiais para fertilizantes minerais, orgânicos, organominerais e corretivos / Ministério da Agricultura, Pecuária e Abastecimento. Secretaria de Defesa Agropecuária. Coordenação-Geral de Apoio Laboratorial; Murilo Carlos Muniz Veras (org.) - Brasília: MAPA/SDA/CGAL, 2014. 220 .

Caione, G.; Lange, A.; Benett, C. G. S.; Fernandes, F. M. Fontes de fósforo para adubação de cana-de-açúcar forrageira no cerrado. Pesquisa Agropecuária Tropical, v.41, p.66-73, 2011. https://doi. org/10.5216/pat.v41i1.8497

Costa, C. H. M. da; Crusciol, C. A. C.; Ferrari Neto, J.; Castro, G. S. A. Residual effects of superficial liming on tropical soil under no-tillage system. Pesquisa Agropecuária Brasileira, v.51, p.16331642, 2016. https://doi.org/10.1590/s0100-204x2016000900063

Costa, S. E. V. G. de A.; Furtini Neto, A. E.; Resende, Á. V. de; Silva, T. O. da; Silva, T. R. da. Crescimento e nutrição da braquiária em função de fontes de fósforo. Ciência e Agrotecnologia, v.32, p.14191427, 2008. https://doi.org/10.1590/S1413-70542008000500010

Cruz, S. J. S.; Oliveira, S. C. de; Cruz, S. C. S.; Machado, C. G.; Pereira, R. G. Adubação fosfatada para a cultura do sorgo granífero. Revista Caatinga, v.22, p.91-97, 2009.

Dias, D. G.; Pegoraro, R. F.; Alves, D. D.; Porto, E. M. V.; Santos Neto, J. A. dos; Aspiazú, I. Production of Piata grass under diferent phosphorus sources. Revista Brasileira de Engenharia Agrícola e Ambiental, v.19, p.330-335, 2015. https://doi.org/10.1590/18071929/agriambi.v19n4p330-335

EMBRAPA - Empresa Brasileira de Pesquisa Agropecuária. Centro Nacional de Pesquisa de Solos. Manual de métodos de análise de solo. 2.ed. Rio Janeiro: Embrapa, 1997. 212p.

Ferreira, D. F. Sisvar: A guide for its bootstrap procedures in multiple comparisons. Ciências e Agrotecnologia, v.38, p.109-112, 2014. https://doi.org/10.1590/S1413-70542014000200001

Fontoura, S. M. V.; Vieira, R. C. B.; Bayer, C.; Ernani, P. R.; Moraes, R. P. de. Eficiência técnica de fertilizantes fosfatados em Latossolo sob plantio direto. Revista Brasileira de Ciência do Solo, v.34, p.19071914, 2010. https://doi.org/10.1590/S0100-06832010000600015
González, L. C.; Prado, R. de M.; Hernández, A. R.; Caione, G.; Selva, E. P. Use of filter cake enriched with rock phosphate and biofertilizers in a Haplustox soil. Pesquisa Agropecuária Tropical, v.44, p.135-141, 2014. https://doi.org/10.1590/S1983-40632014000200001

Monteiro, C. M. Fosforitos do Grupo Bambuí na região de Campos Belos (GO)/Arraias (TO), na borda oeste do Cráton São Francisco. Brasília: Universidade de Brasília, 2009. 129p.

Oliveira, P. P. A.; Oliveira, W. S. de; Corsi, M. Efeito residual de fertilizantes fosfatados solúveis na recuperação de pastagem de Brachiaria brizantha cv. marandu em Neossolo Quartzarênico. Revista Brasileira de Zootecnia, v.36, p.1715-1728, 2007. https:// doi.org/10.1590/S1516-35982007000800003

Ono, F. B.; Montagna, J.; Novelino, J. O.; Serafim, M. E.; Dallasta, D. C.; Garbiate, M. V. Eficiência agronômica de superfosfato triplo e fosfato natural de Arad em cultivos sucessivos de soja e milho. Ciência e Agrotecnologia, v.33, p.727-734, 2009. https://doi. org/10.1590/S1413-70542009000300010

Parente, H. N.; Silva Júnior, O. R. da; Bandeira, J. R.; Parente, M. de O. M.; Rodrigues, R. C.; Rocha, K. S. da. Produtividade do sorgo forrageiro em função de quantidades crescentes de adubação fosfatada e nitrogenada. Revista Trópica: Ciências Agrárias e Biológicas, v.8, p.1-10, 2014.

Pereira, R. G.; Oliveira, F. H. T. de; Silva, G. F. da; Paiva, M. R. de F. C.; Novo Júnior, J. Rendimento do sorgo granífero adubado com nitrogênio e fósforo no semiárido brasileiro. Revista Brasileira de Milho e Sorgo, v.13, p.284-299, 2015.

Predebon, R.; Gatiboni, L. C.; Oliveira, C. M. B.; Cassol, P. C.; Oliveira, D. E. de. Doses de calcário e modo de incorporação na reaplicação em pastagem perene de Tifton (Cynodon spp.). Revista de Ciências Agroveterinárias, v.9, p.39-47, 2010.

Resende, A. V. de; Furtini Neto, A. E.; Alves, V. M. C.; Muniz, J. A.; Curi, N.; Faquin, V.; Kimpara, D. I.; Santos, J. Z. L.; Carneiro, L. F. Fontes e modos de aplicação de fósforo para o milho em solo cultivado da região do cerrado. Revista Brasileira de Ciência do Solo, v.30, p.453466, 2006. https://doi.org/10.1590/S0100-06832006000300007

Restelatto, R.; Menezes, L. F. G. de; Paris, W.; Sartor, L. R.; Martin, T. N.; Herrera, W. F. B.; Pavinato, P. S. Sorghum and black oat forage production and its nutritive value under phosphate levels. Revista Semina: Ciências Agrárias, v.38, p.429-442, 2017. https://doi. org/10.5433/1679-0359.2017v38n1p429

Silva, F. C. S. Manual de análises químicas de solos, plantas e fertilizantes. Brasília: Embrapa Informação Tecnológica/ Rio de Janeiro: Embrapa Solos, 2009. 627p.

Souza, R. M. de; Sobral, L. F.; Viégas, P. R. A.; Oliveira Júnior, A. de; Carvalho, M. da C. S. Eficiência agronômica de fosfatos de rocha em solo com elevado teor de cálcio trocável. Revista Brasileira de Ciência do Solo, v.38, p.1816-1825, 2014. http://dx.doi.org/10.1590/ S0100-06832014000600016

Taiz, L.; Zeiger, E. Fisiologia vegetal. 5.ed. Porto Alegre: Artmed, 2013. 954p.

Too, E. J.; Were, B. A.; Onkware, A. O.; Ringo, J. H.; Kisinyo, P.; Carlsson, A. S.; Ouma, E.; Geleta, M.; Gudu, S. Response of selected sorghum (Sorghum bicolor L. Moench) germplasm to aluminium stress. African Journal of Agricultural Research, v.9, p.1651-1662, 2014. https://doi.org/10.5897/AJAR2013.7795 